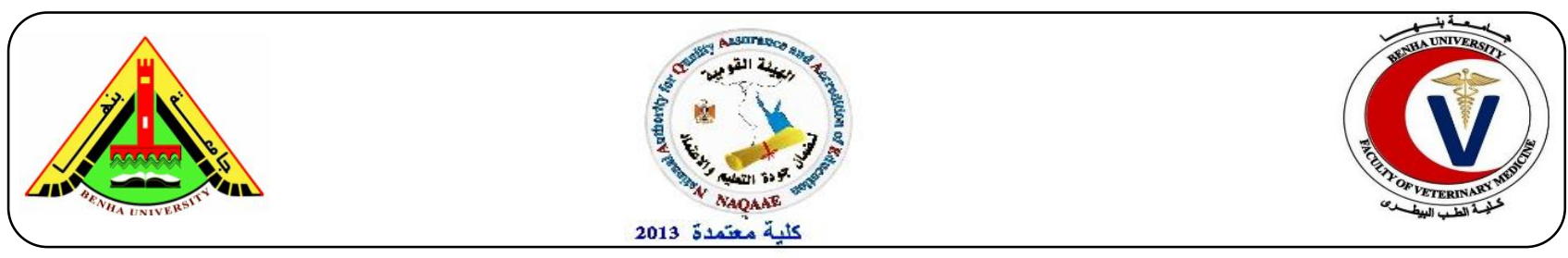

\title{
Effect of some Dietary Supplementation on Economic Efficiency of Laying Japanese Quail
}

\section{Seham Fawzy Shehata ${ }^{1 *}$, Eman Ramadan Kamel ${ }^{1}$, Mohammed El-Sayed Abo-Salem ${ }^{2}$ and Sanad Talaat Atallah ${ }^{3}$}

${ }^{1}$ Department of Animal Wealth Development, Faculty of Veterinary Medicine, Benha University

${ }^{2}$ Department of Forensic Medicine and Toxicology, Faculty of Veterinary Medicine, Benha

University.

${ }^{3}$ Department of Animal Husbandry and Animal Wealth Development, Faculty of Veterinary

Medicine, Alexandria University.

*To whom correspondence should be addressed. E-mail: seham.shehata@fvtm.bu. edu.eg

\section{A B S T R A C T}

This work was conducted to study the effect of sun dried tomato pomace (SDTP) with or without enzymes supplementation on economic efficiency of laying Japanese quail. A total of 144 forty-five days-old female Japanese quails were used. The hens were randomly allocatted into 6 groups (24 hens per each group which subdivided into 3 replicates each one contains 8 females.). Group 1 was fed on the basal diet (BD) (control), group 2 were fed on the BD containing AveMix ${ }^{\circledR}$ $02 \mathrm{CS}$ enzyme $0.2 \mathrm{~g} / \mathrm{kg}$ diet. While hens of group 3 were fed BD containing $2.5 \%$ SDTP). Group 4 received BD containing 2.5\% SDTP with AveMix ${ }^{\circledR} 02 \mathrm{CS}$ enzyme. Group 5 received BD containing 5\% SDTP. Group 6 received BD containing 5\% SDTP with AveMix® 02 CS enzyme. From the obtained results it was observed that, the increasing $2.5 \%$ SDTP resulted in an increase of egg mass by $11.08 \%$. In addition to, enzymes addition leads to increasing weight of egg mass and decrease of TC by $0.82 \%$.

Keywords: Japanese quail, tomato pomace, Enzymes, economic efficiency.

(http://www.bvmj.bu.edu.eg)

(BVMJ-34(1): 209-218, 2018)

\section{INTRODUCTION:}

In Southeast Asia and Japan. But meat is the main product in Europe. Also, Japanese quails cheracterized by low maintenance cost associated with its small body size (80-300 g) plus its short generation interval, resistance to diseases and high egg production, and laboratory animal. Tunsaringkarn et al., (2013) stated that quail eggs are the good source of nutrients for human health. Regular consumption of quail eggs helps fight against many diseases which are a natural combatant against digestive tract disorders such as gasteritis. Quail eggs improve the immune system, promote memory health, increase brain activity and stabilize the nervous system. They are excellent sources of 
protein, fat, vitamin $\mathrm{E}$ and minerals such as nitrogen, iron, and zinc. Giovanelli et al., (2002) said that rising costs of cereals and imported feedstuffs for poultry diets have resulted in a search for alternative ingredients that would be available as by-products from local agricultural industries. Also, Salajegheh et al., (2012) reported that Agro-Industrial By-Products AIBP represented one of the most talented and promising energy and protein sources supply for livestock. The use of AIBP as a part of the feed for livestock has a high value starting from reducing the cost of production and ultimately increasing the profit margin of livestock farmers.

Sogi et al., (2005) said that the remained solid waste after processing of tomato consists of skin, seeds, trimmings, cores, fibrous matter and cull tomato. The effect of diet containing of SDTP on laying economic parameters is enigmatic. Therefore, this study was carried out to investigate the effect of diets containing two levels (2.5 and 5\%) of SDTP with or without AveMix ${ }^{\circledR} 02$ CS enzyme on economic efficiency of laying quail.

\section{MATERIALS AND METHODS:}

\subsection{Experimental Chicks:}

Our study was carried out at the quail production unit of the faculty of veterinary medicine Moshtohor, Benha University. Department of Animal Wealth Development,at the period extended from $11^{\text {th }}$ April 2015 to $30^{\text {th }}$ may. A total of 144 42-day old Japanese hens were used in this study. In which each group contains 24 females which subdivided into (3) replicates each one contains 8females.

\subsection{Management and Housing:}

The hens housed in 2 battery cages; each cageconsisted of 10 departments. They were housed in a clean well-ventilated room, previously disinfected with formalin. The hens were housed in a clean well-ventilated room. Feed and water were supplied adlibitum.

\subsection{Experimental Diets:}

2.3.1. Tomato pomace obtained from commercial processors (Hienz company, $6^{\text {th }}$ October City, Egypt). It dried by spreading on a plastic sheet with exposing to sunlight. The particle size of pomace reduced by beating using stick and hand crushing according to Yitbarek, (2013).

\subsubsection{Enzyme description:}

AveMix ${ }^{\circledR} 02$ CS enzyme, a commercial multi enzyme containing glucanase, endo-1,4- $\beta$ xylanase and pectinase added to enzyme supplemented diet at the rate of $0.2 \mathrm{~g} / \mathrm{kg}$ diet.

Quail hens were randomly sorted into six experimental groups and were fed ad libitum on the 6 different experimental diets until the end of the experiment.

\subsection{Studied traits:}

\subsubsection{Egg production traits:}

\subsubsection{Egg mass:}

The average egg weight $(\mathrm{g})$ for each replicate multiplied by the egg number weekly calculated according to Jalalinasab et al., (2014).

Economic efficiency measurements:

The most important economic efficiency parameters studied include the following:

\section{Total costs (TC):}

It calculated from the summation of total fixed costs and total variable costs. 


\section{b. Total returns (TR):}

- Total returns $=$ Litter sale + egg sale+ hen sales.

- Litter sale $=$ Litter sale price $/$ No. of quail at the end of theproject.

- Egg sale $=$ number of eggs $\mathrm{x}$ price of an egg.

- Hen sale = Body weight/gmat the end of project $x$ Gram price.

\subsubsection{Production and cost function:}

\subsubsection{Production function}

Logarithmic form was the best for determination the production model to estimate the effect of partial substitution of yellow corn and soya bean meal with sun dried tomato pomace on egg mass for laying hens for each group.

\subsection{Costs function:}

Logarithmic form was carried out to estimate

\subsubsection{2.a. Effect of egg mass on total cost}

The egg mass used as (independent variable) and total cost used as (dependant variable).

\subsubsection{2.b. Effect of total return on total costs}

The total return used as (independent variable) and total cost used as (dependant variable) according to Fardos (2009).

\section{RESULTS:}

3.1. Effect of dietary supplement cost on total egg mass.

3.1.1. Effect of dietary supplement on total egg mass.

\subsection{Cost functions:}

3.2.1. Relationship between Egg mass and Total Costs of laying quail.

3.2.2. The relationship between Egg mass and Total Costs of laying quail in 5\% DTP groups. 
Table (1): Experimental design for all treared groups.

\begin{tabular}{ccl}
\hline Group & Number of birds & Diets \\
\hline 1 & 24 & Control- Basal diet only \\
\hline 2 & 24 & D1- Basal diet with enzymes. \\
3 & 24 & D2 - Basal diet containing (2.5\% SDTP) \\
4 & 24 & D3 - Basal diet containing (2.5\% SDTP plus enzymes). \\
5 & 24 & D4 - Basal diet containing (5\%) SDTP. \\
6 & 24 & D5 - Basal diet containing (5\%) SDTP plus Enzymes.
\end{tabular}

Table (2): Production Function of egg mass and dietary supplement for of (2.5\%) SDTP group.

\begin{tabular}{ll}
\hline Function & Log egg mass $=1.924+1.108$ log dietary \\
$\mathrm{t}$ & $(77.534)^{*}(20.344)^{*}$ \\
$\mathrm{~F}$ & $(348.924)^{*}$ \\
$\mathrm{R}^{-2}$ &
\end{tabular}

(0.949)

** Significant at $(P \leq 0.05)$. 
Table (3): Production Function of egg mass and dietary supplement for of (2.5\%) SDTP with Enzyme group.

Function

Log egg mass $=1.124+.835 \log$ dietary supplement

$\mathrm{T}$

$$
(8.489)^{* *}(9.728)^{* *}
$$

$\mathrm{F}$

$\mathrm{R}^{-2}$

$(94.640)^{* *}$

$(0.803)$

** Significant at $(P \leq 0.05)$.

Table (4): Production Function of egg mass and dietary supplement for (5\%) SDTP with enzymes group.

\begin{tabular}{|c|c|}
\hline Function & Log egg mass $=6.163-2.007$ log dietary supplement \\
\hline $\mathrm{t}$ & $(13.228)^{* *}(-7.988)^{* *}$ \\
\hline \multicolumn{2}{|l|}{$\mathrm{F}$} \\
\hline \multirow[t]{2}{*}{$\mathrm{R}^{-2}$} & $(63.811)^{* *}$ \\
\hline & $(0.732)$ \\
\hline
\end{tabular}

Table (5): Cost Function of egg mass and total cost for control group

\begin{tabular}{ll}
\hline Function & Log total costs $=2.452+0.272$ log egg mass \\
$\mathrm{t}$ & $(36.342)^{* *}(9.744)^{* *}$ \\
$\mathrm{~F}$ & $(94.947)^{* *}$
\end{tabular}

(0.803)

** Significant at $(P \leq 0.05)$. 
Table (6): Cost Function of egg mass and total cost for Control with enzymes group

\begin{tabular}{|c|c|}
\hline Function & Log total costs $=3.288-0.082 \log$ egg mass \\
\hline $\mathrm{t}$ & \\
\hline $\mathrm{F}$ & $(26.556)^{* *}(-1.606)^{* *}$ \\
\hline $\mathrm{R}^{-2}$ & $(2.578)^{* *}$ \\
\hline & $(0.64)$ \\
\hline
\end{tabular}

Table (7): Cost Function of egg mass and total cost for (2.5\%) SDTP group

\begin{tabular}{ll}
\hline Function & Log total costs $=2.532+0.227 \log$ egg mass \\
$\mathrm{t}$ & $(18.702)^{* *}(4.063)^{* *}$ \\
$\mathrm{~F}$ & $(16.510)^{* *}$ \\
$\mathrm{R}^{-2}$ & $(0.413)$
\end{tabular}

** Significant at $(P \leq 0.05)$.

Table (8): Cost Function of egg mass and total cost for $2.5 \%$ SDTP with enzymes group.

\begin{tabular}{ll}
\hline Function & Log total costs $=2.539+0.307$ log egg mass \\
$\mathrm{T}$ & $(22.275)^{* * *}(6.988)^{* * *}$ \\
$\mathrm{~F}$ & $(87.726)^{* * *}$ \\
$\mathrm{R}^{-2}$ & $(0.675)$
\end{tabular}

** Significant at $(P \leq 0.05)$. 
Table (9): Cost Function of egg mass and total cost for (5\%) SDTP group

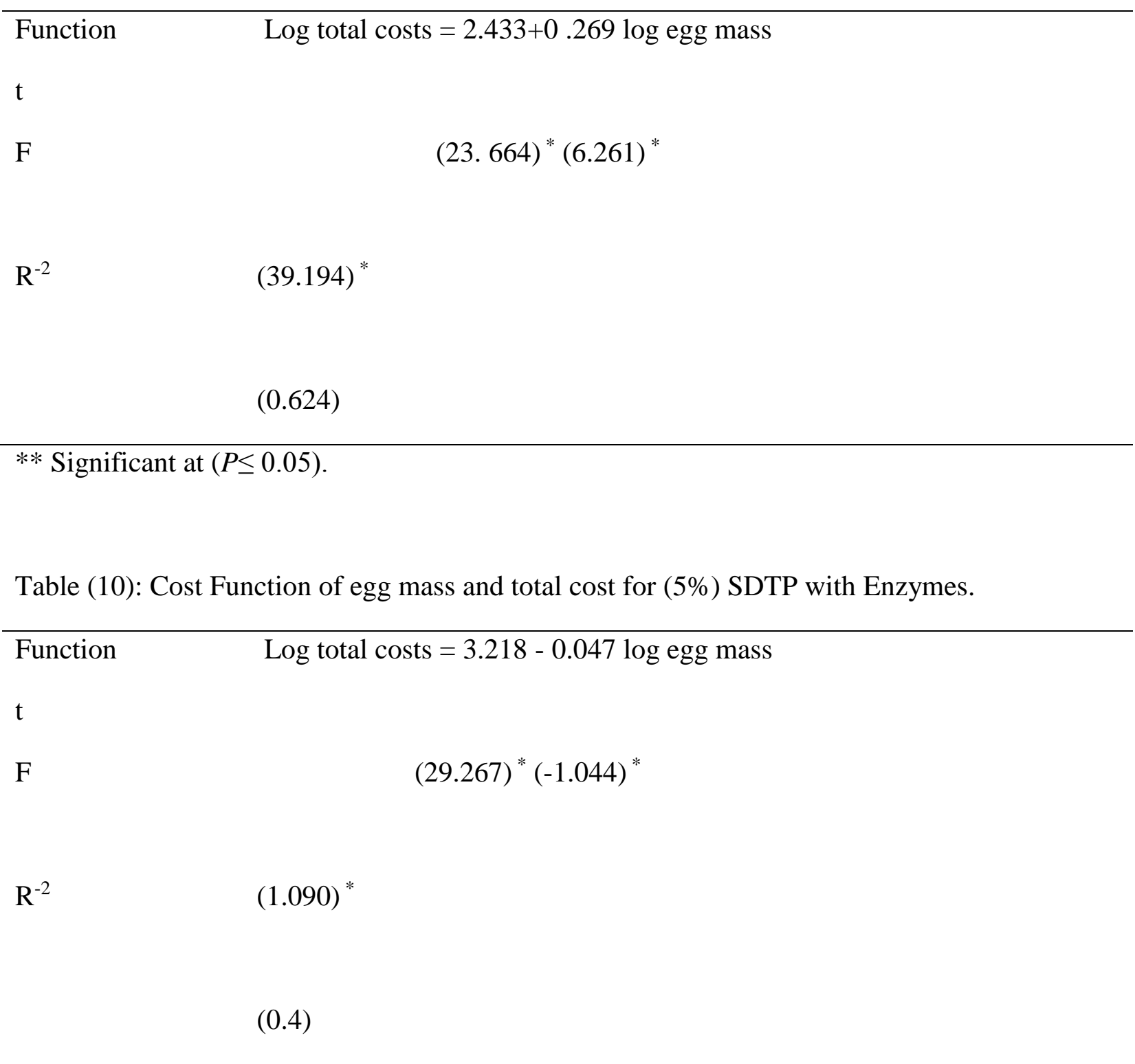

Table (11): Cost Function of total return and total cost for Control group:

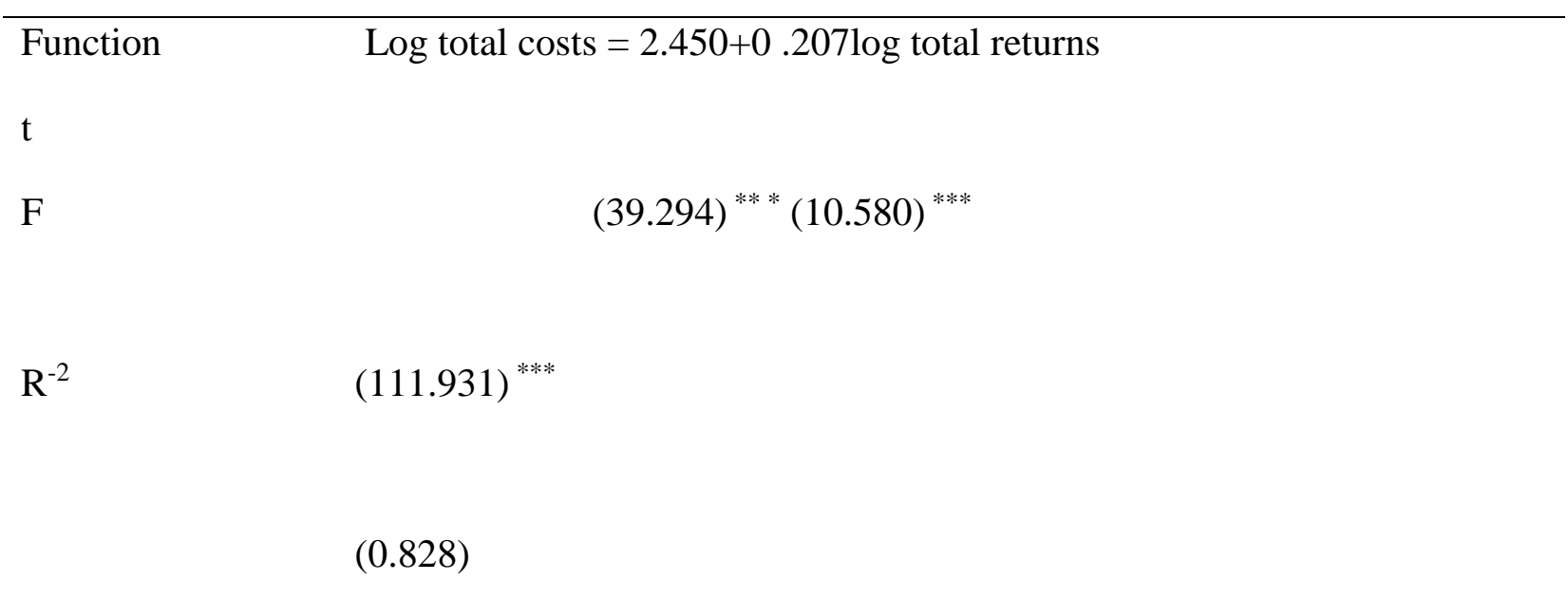

** Significant at $(P \leq 0.05)$. 
Table (12): Cost Function of total return and total cost for (2.5\%) SDTP group:

\begin{tabular}{|c|c|}
\hline Function & Log total costs $=2.626+0.144 \log$ total returns \\
\hline $\mathrm{t}$ & \\
\hline $\mathrm{F}$ & $(24.353)^{* * *}(4.238)^{* * *}$ \\
\hline $\mathrm{R}^{-2}$ & $(17.959)^{* * *}$ \\
\hline
\end{tabular}

** Significant at $(P \leq 0.05)$.

Table (13): Cost Function of total return and total cost for (2.5\%) SDTP with enzymes group.

Function $\quad$ Log total costs $=2.597+0.158 \log$ total returns

$\mathrm{t}$

$\mathrm{F}$

$(29.061)^{* * *}(5.614)^{* * *}$

$\mathrm{R}^{-2}$

$(31.513)^{* * *}$

$(0.570)$

** Significant at $(P \leq 0.05)$.

\section{DISCUSSION:}

Regarding table (3), The average elasticity of dietary supplement cost was about (0.835), meaning that the increasing dietary supplement cost by $10 \%$ resulted in an increase of egg mass by $8.35 \%$ and the dietary supplement explained about $80 \%$ from changes in total egg mass.
In regard to table (4), the average elasticity of dietary supplement cost was about (-2.007), meaning that the increasing dietary supplement by $10 \%$ resulted in a decrease of egg mass by $20.07 \%$. This may be due to high fiber content in 5\% SDTP.

The table (5) showed the significant $(P \leq 0.05)$ of the production function and positive relationship total egg mass and total cost. The average elasticity of egg mass was 
about (+0 .272), meaning that the increasing weight of egg mass by $10 \%$ resulted in an increase of TC by $2.72 \%$ and the value of dietary supplement explained about $80 \%$ from changes in TC.

In table (6), the average elasticity of egg mass was about (- 0 .082), meaning that the increasing weight of egg mass by $10 \%$ resulted in a decrease of TC by $0.82 \%$ and the value of dietary supplement explained about $6.4 \%$ from changes in TC.

The table (7) showed the significant $(P \leq 0.05)$ of the production function and positive relationship total egg mass and total cost. The average elasticity of egg mass was about (+0 .227), meaning that the increasing weight of egg mass by $10 \%$ resulted in an increase of TC by $2.27 \%$ and the value of feed substitution explained about $41.3 \%$ from changes in TC.

As showen in table (8) the significant $(P \leq 0.05)$ of the production function and positive relationship total egg mass and total cost. The average elasticity of egg mass was about (+0 .307), meaning that the increasing weight of egg mass by $10 \%$ resulted in an increase of TC by $3.07 \%$ and dietary supplement addition explained about $67 \%$ from changes in TC.

Table (9) indicated the significant $(P \leq$ 0.05 ) of the production function and positive relationship total egg mass and total cost. The average elasticity of egg mass was about $(+0$
.269), meaning that the increasing weight of egg mass by $10 \%$ resulted in an increase of TC by $2.69 \%$.

Concerning table (10), The average elasticity of egg mass was about (-0. 047), meaning that the increasing egg mass by $10 \%$ resulted in decrease $\mathrm{TC}$ by $0.47 \%$ and the value of dietary supplement explained about 4 $\%$ from changes in TC.

The table (11) showed the significant $(P \leq 0.05)$ of the production function and positive relationship total return and total cost. The average elasticity of TR was about (+0 .207), meaning that the increasing TR by $10 \%$ resulted in an increase of TC by $2.07 \%$.

Table (12) indicated the significant $(P$ $\leq 0.05)$ of the production function and positive relationship total return and total cost. The average elasticity of TR was about (+0 .144), meaning that the increasing TR by $10 \%$ resulted in an increase of TC by $1.44 \%$. As addition of SDTP decrease total cost. This result is in accordance by Patwardhan et al., (2011) who saidthe use of tomato processing byproducts could provide extra income.

Table (13) showed the significant $(\mathrm{P} \leq$ 0.05) of the production function and positive relationship total return and total cost. The average elasticity of TR was about (+0 .158), meaning that the increasing TR by $10 \%$ resulted in an increase of TC by $1.58 \%$. From our study, we conclude that the increasing $2.5 \%$ SDTP resulted in an increase of egg 
mass by $11.08 \%$. In addition to, enzymes addition leads to increasing weight of egg mass and decrease of TC by $0.82 \%$.

\section{REFERENCES:}

Ekenyem, B.U. and Madubuike, F.N. (2006): An assessment of Ipomoea asarifolia leaf meal as feed ingredient in broiler chick production. Pak. J. Nutr. 5: 46-50.

Fardos, A.Hassan., (2009): Effect of Some Feed Additives on Economic and Productive Efficiency of Broilers. Master degree, . faculty of veterinary medicine, Zagazig University Egypt.

Giovanelli, G.; Zanoni, B.; Lavelli, V.; and Nani, R. (2002): Water sorption, drying and antioxidant properties of dried tomato products. J. Food Eng. 52, 135141.

Jalalinasab, A.; Nobakht, A. and Razzaghzadeh, S. (2014): The Effects of Different Levels of Tomato Pomace and Processing Methods on Production Performance and Blood Metabolites of Native Laying Hens. Iranian Journal of Applied Animal Science. Volume: 4; Number: 2; Pages: 379-385.

Patwardhan, D.S.; King, A.J. and Mireles, A. (2011): Tomato pomace and safflower meal as ingredients in non-feed-removal molt diets. J. Appl. Poult. Res. 20:291302.
Safamehr, A.; Malek, H. and Nobakht, A. (2011): The effect of different levels of tomato pomace with or without multi enzyme on performance and egg traits of laying hens. Iranian J.Anim.Sci. 1(1), 3948.

Salajegheh, M.H.; Ghazi, S.; Mahdavi, R. and Mozafari, O. (2012): Effects of different levels of dried tomato pomace on performance, egg quality and serum metabolites of laying hens. African Journal of Biotechnology Vol. 11(87), pp. $15373-15379$.

Sogi, D.S.; Bhatia, R.; Garg, S.K. and Bawa, A.S. (2005): Biological evaluation of tomato waste seed meals and protein concentrate. Food Chemistry, 89: 53-56.

Tunsaringkarn, T.; WannaTungjaroenchai, W. and Siriwong, W. (2013): Nutrient Benefits of quail (CoutrnixCoutrnix Japonica) eggs. International Journal of Scientific and Research Publications, Volume 3, Issue 5, 1-8.

Vali, N (2009): Growth, Feed consumption and Carcass composition of Coutrnix Japonica ypsilphorus and their reciprocal crosses. Asian journal of poultry science. 3. (4):132-137.

Yitbarek, M.B. (2013): The effect of feeding different levels of dried tomato pomace on the performance of Rhode Island Red (RIR) grower chicks. Global Journal of Poultry Farming and Vaccination. Vol. 1 (1), pp. 052-058. 